\title{
RECHTSREGEL
}

Jurnal Ilmu Hukum Vol 1, No 2 Desember 2018

P-ISSN 2622-6235, E-ISSN 2622-6243,

rjih_fh@unpam.co.id

\section{PERKAWINAN DALAM AJARAN KHONG HU CU DITINJAU DARI UU NO. 1 TAHUN 1974 TENTANG PERKAWINAN PASCA TAHUN 2000}

\author{
Siti Nurwullan \\ Fakultas Hukum Universitas Pamulang \\ Email : wulancitra228@gmail.com
}

Received: - /Revised: - /Accepted: Des 2018

\begin{abstract}
ABSTRAK
Indonesia adalah bangsa pluralisme yang memiliki keanekaragaman budaya dan agama, menuntut masyarakatnya untuk saling menghargai keyakinan masing-masing di mana masyarakat tersebut adalah masyarakat pribumi dan pendatang. Salah satu masyarakat pendatang yang memiliki populasi cukup dominan di Indonesia adalah Masyarakat Tionghoa yang berasal dari Negeri Cina yang juga identik dengan kebudayaan Tionghoa dan Agama Khonghucunya. mengingat Agama Khonghucu tergolong baru pengakuannya secara resmi oleh Pemerintah Indonesia, yang otomatis sangat berpengaruh pada Status Hukum Perkawinan Khonghucu, dimana peristiwa perkawinan tersebut sangat penting bagi pasangan antara laki-laki dan perempuan yang sepakat mengikatkan diri dalam suatu ikatan perkawinan dengan tujuan membentuk suatu keluarga dan meneruskan keturunan. Status hukum juga akan berpengaruh bagi anak-anak dari dari hasil perkawinan tersebut maka akan di bahas bagaimana Perkawinan dalam Ajaran Khonghucu bila dikaitkan dengan UU No.1 Tahun 1974 Tentang Perkawinan.
\end{abstract}

KATA KUNCI : Agama, Perkawinan, Keabsahan dan Kepastian hukum

\section{ABSTRACT}

Indonesia is a nation of pluralism that has a diversity of cultures and religions, demanding that its people respect each other's beliefs where the community is indigenous and immigrant. One of the migrant communities that has a dominant population in Indonesia is the Chinese community originating from China which is also synonymous with Chinese culture and the Confucian Religion. considering Confucianism is officially recognized by the Indonesian 
Government, which automatically has a profound influence on Confucian Marriage Legal Status, where the marriage is very important for couples between men and women who agree to bind themselves in a marriage bond with the aim of forming a family and continue descent.

\section{KEY WORDS: Religion, Marriage, Legality and Legal Certainty}

\section{PENDAHULUAN}

Manusia adalah mahluk paling sempurna di muka bumi, dia memiliki akal budi dan kehendak yang bebas dibalut oleh jasmani dalam bentuk raga dan rohani. Namun walaupun demikian sempurna manusia tidak bisa hidup sendiri dia tetap membutuhkan manusia lain dalam kehidupannya, untuk itu manusia dikatakan mahluk sosial. Sebagai mahluk sosial manusia memiliki banyak kebutuhan tidak hanya kebutuhan jasmani berupa makan, minum dan pakaian tetapi juga memiliki kebutuhan rohani seperti pendidikan, keyakinan, dan teman dalam kehidupannya. Dalam bermasyarakat manusia memiliki aturan hidup, hukum dan norma yang harus dipatuhi, salah satunya adalah norma agama selain norma hukum yang menjadi acuan dan pedoman dalam kehidupannya. Indonesia memiliki banyak agama besar yang tumbuh dan berkembang sejak ribuan tahun lalu, seperti agama Islam, Kristen Katolik, Kristen Protestan, Hindu, Budha dan Khong hu cu. Saat ini penulis ingin mengangkat Agama Khong hucu dimana agama tersebut baru diakui oleh negara pada tahun 2000 melalui Keppres No. 6 Tahun 2000 Tentang pencabutan Instruksi Presiden No. 14 tahun 1967 Tentang Agama dan Kepercayaan serta Adat Istiadat Cina dimana kebijakan tersebut sangat berpengaruh besar pada kepastian hukum, status hukum dan pelaksanaan ritual agama para penganutnya. Dikarenakan hal ini sangat berpengaruh pada kepastian hukum 
maka penulis ingin membahas melalui tema perkawinan dalam ajaran Khong hu cu di tinjau dari Undang-undang No. 1 Tahun 1974 Tentang Perkawinan." Dimana pernikahan dalam pemahaman ajaran Kong hu cu adalah pertautan antara Khian dan Khun yang berarti perkawinan antara laki-laki dan perempuan yang membentuk ikatan lahir batin dalam suatu rumah tangga yang akan melahirkan keturunan anak manusia yang dalam hal ini merupakan Firman Tuhan atau kodrat bagi para penganutnya."1

Kebebasan beragama dan perlindungan hukum terhadap agama dari Negara sudah di jamin berdasarkan Pancasila dan Undang-undang Dasar 1945. Artinya dengan diterimanya Pancasila sebagai asas tunggal oleh para penganut agama khong hu cu menyatakan aktifitas mereka dalam menjalankan ritual akan selalu berpedoman pada nilai-nilai Pancasila tersebut, termasuk pula dalam proses Indonesianisasi, ini terjadi karena penganut agama khong hu cu berasal dari Tionghoa Cina yang masuk ke Indonesia sejak ribuan tahun lalu. Sampai saat ini agama khonghucu masih belum jelas statusnya, apakah masuk agama atau kepercayaan karena dikalangan masyarakat penganutnya belum ada keseragaman ajaran. Kitab suci khonghucu adalah kitab Su Si dan Ngo King, kedua kitab tersebut adalah merupakan suatu hasil karya besar seorang cerdik pandai yang berisi tentang ajaran-ajaran filsafat dan kode-kode etik yang dapat dijadikan landasan hidup dan bertidak para penganutnya, yang tentunya tidak bertentangan dengan Pancasila. Berdasarkan pasal 29 Undang-undang Dasar 1945 Tentang Kebebasan

\footnotetext{
${ }^{1}$ Soetandyo Wignyosoebroto, Perspektif Pekawinan Ditinjau Dari Sudut Hukum, Sosial dan Agama Khonghucu. Surabaya : Penelitian dan Pengembangan Majelis Agama Khonghucu Indonesia. Edisi II Boen Bio, 1997.Hal 7
} 
Beragama ayat (1) Negara berdasar atas Ketuhanan Yang Maha Esa, ayat (2) Negara menjamin kemerdekaan tiap-tiap penduduk untuk memeluk agamanya masing-masing dan untuk beribadat menurut agamanya dan kepercayaannya itu. Dari paparan tersebut jelaslah bahwa negara menjamin keberadaan agama dan para penganutnya di Indonesia.

Namun faktanya sebalum tahun 2000, kebebasan para penganut agama Khonghucu sangat terbatas baik dalam pelaksanaan ritual agama, pelaksanaan hari raya keagamaan, acara agama dalam menyelenggarakan perkawinan sampai pada status hukum para penganutnya yang tentu saja hal ini sangat berpengaruh terhadap kepastian hukum dan status hukum mereka secara keseluruhan dikarenakan kebijakan politik pada masa orde baru. Karena hal tersebut penulis sangat tertarik dengan permasalahan ini karena walaupun telah lama berlalu namun dampak dari hal tersebut tidak bisa serta merta bisa diperbaiki secara cepat dan menyeluruh. Dan hal ini pun menjadi perhatian khusus bagi penulis untuk mengadakan penelitian yaitu: 1 . Bagaimanakah legalitas perkawinan secara Agama Khonghucu di tinjau dari Undang-undang No. 1 Tahun 1974 Tentang perkawinan?, 2. Apakah masih ada akibat hukum yang negatif bagi para penganut agama konghucu saat ini ?, untuk itu penulis mengambil judul " PERKAWINAN DALAM AJARAN KHONG HU CU DI TINJAU DARI UNDANG-UNDANG NO. 1 TAHUN 1974 TENTANG PERKAWINAN PASCA TAHUN 2000 (Studi di Desa Curug Gunung Sindur Bogor)".

\section{PERMASALAHAN}

Dari uraian latar belakang masalah di atas, penulis tertarik mengangkat masalah yang akan diteliti dalam penulisan ini yaitu: 
1. Bagaimanakah legalitas perkawinan secara agama kong hucu di tinjau dari Undang-undang No. 1 Tahun 1974 Tentang perkawinan?

2. Apakah masih ada akibat hukum yang negatif bagi para penganut agama khonghucu saat ini?

\section{TUJUAN DAN MAMFAAT PENELITIAN}

1. Tujuan Penelitian

a. Untuk memenuhi syarat tugas sebagai tenaga pengajar Universitas Pamulang.

b. Untuk mengetahui alasan pembekuan Agama Khonghucu di Indonesia.

2. Mamfaat penelitian

a. Untuk membantu dan menyumbangkan pikiran dalam rangka menyelesaikan permasalahan di bidang agama yang khususnya menyangkut dengan Agama Khonghucu.

b. Memberikan masukan-masukan kepada dunia akademis dan praktisi khususnya dalam menyelesaikan masalah sehubungan dengan perkawinan menurut Agama Khonghucu.

\section{METODE PENELITIAN}

Metode pengumpulan data yang kami gunakan untuk menunjang dan memperkaya tulisan ini adalah dengan :

1. Metode pendekatan

Dalam penulisan ini digunakan empiris normatif, yaitu dengan cara meneliti bahan pustaka dan menelaah data sekunder, sifat dari penelitian ini adalah deskriptif analisis yaitu penelitian dilakukan dengan mengkaji dan menganalisa gejala-gejala yang terjadi di dalam masyarakat yang bersumber dari data lapangan di peroleh dari studi 
empiris dengan cara mewancarai orang-orang yang kompeten dengan judul tulisan ini. oleh karena itu untuk membahas masalah yang ada dipergunakan metode yuridis normatif, yang mana pendekatan (statute approah) dikaitkan dengan permasalahan yang didasarkan pada peraturan-peraturan yang berlaku. yaitu dengan Undangundang No.1 Tahun 1974 dikaitkan dengan pelaksanaan perkawinan secara Khonghucu sehingga dapat tercapai suatu kejelasan dan sinkronisasi dalam pemecahan permasalahan.

2. Sumber data

Penelitian hukum yang bersifat normatif selalu menitik beratkan pada data sekunder. Data sekunder pada penelitian dapat dibedakan menjadi :

a. Bahan hukum primer atau bahan hukum lapangan adalah bahan hukum yang diperoleh dari hasil wawancara pihak-pihak yang terlibat dalam permasalahan di tulisan ini, seperti Pemuka Agama Khonghucu beserta para penganutnya.

b. Bahan hukum sekunder atau bahan hukum kepustakaan adalah bahan hukum yang berasal dari berbagai bukubuku, literatur, bahan kuliah, makalah, karya ilmiah, artikel yang berhubungan dengan masalah yang di bahas baik yang berasal dari majalah atau internet, dan peraturan perundang-undangan yang berlaku.

\section{PEMBAHASAN}

Tidak dapat dipungkiri dengan banyak budaya yang dimiliki oleh Bangsa Indonesia sangat berpengaruh pada tata cara perkawinan yang berbeda-beda pula, sesuai dengan pendapat salah satu ahli mengatakan bahwa, "kadang kala perkawinan itu dipengaruhi oleh pengetahuan, pengalaman (kebiasaan), keagamaan, kepercayaan yang dianut masyarakat yang 


\section{Siti Nurwullan}

bersangkutan."2 Hal ini menjadi masalah serius bagi pemerintah Indonesia pada saat itu dalam pencatatan status hukum masyarakatnya. Sebelum lahir Undang-undang No. 1 Tahun 1974 Tentang perkawinan, terdapat tiga golongan masyarakat di Indonesia yaitu golongan Eropa, golongan Timur Asing dan golongan Pribumi yang masing-masing golongan tersebut sudah memiliki aturan hukum dan adat istiadatnya sendiri. Seperti:

1. Golongan Pribumi untuk urusan hukumnya memakai hukum Islam dan hukum adat.

2. Golongan Eropa untuk urusan hukumnya memakai hukum Perdata dan

3. Golongan Timur asing untuk urusan hukumnya memakai hukum perdata dan atau hukum adatnya sendiri yang dibawa dari negeri asal.

Untuk penyeragaman status hukum dan penyelanggaraan ketertiban umum secara keseluruhan bagi rakyat Indonesia khususnya dalam hal perkawinan maka pemerintah Indonesia mengeluarkan Undang-undang No. 1 Tahun 1974 Tentang perkawinan, namun tidak mudah bagi Pemerintah melakukan penyeragaman hukum tersebut karena masing-masing golongan dan suku sudah mempunyai aturan hukum sendiri. Khususnya masyarakat Tionghoa yang kala itu memiliki jumlah yang cukup dominan untuk kalangan minoritas dan mereka mempunyai keyakinan, agama, dan adat istiadat sendiri yang sangat kental warisan dari leluhur mereka yang dibawanya dari negeri asal, dimana hal tersebut di anggap menghalangi proses asimilasi atau pembauran masyarakat Indonesia yang plural oleh Pemerintah

${ }^{2}$ Hilman Hadi Kusuma, Hukum Perkawinan Indonesia, Mandar Maju Bandung, 1990.hal 37 
Indonesia saat itu. Hal ini bisa dikaji melalui data yang penulis dapatkan yaitu:

1. Pada awal setelah Indonesia merdeka dalam segala bentuk peraturan yang dikeluarkan Pemerintah tidak ada klasifikasi agama yang diakui atau tidak diakui sebagai agama resmi Indonesia.

2. Melalui Penetapan Presiden Republik Indonesia No. 1 Tahun 1965 tentang Pencegahan Penyalahgunaan dan atau Penodaan Agama dalam penjelaasannya tertulis bahwa : "agama-agama yang dipeluk oleh Penduduk Indonesia ialah Islam, Kristen, Katolik, Hindu, Budha, dan Khonghucu (Congfusiua)".

Berdasarkan peraturan tersebut jelaslah pada awalnya agama konghucu pernah menjadi agama resmi di Indonesia.

3. Tahun 1967, tepatnya di tanggal 30 September 1967 di Indonesia telah terjadi peristiwa berdarah yang menyebabkan 7 jendral besar menjadi korban, peristiwa tersebut dikenal dengan G 30 S PKI atau Gerakan 30 September Partai Komunis Indonesia. Peristiwa tersebut merupakan bentuk pemberontakan dari salah satu partai atau elite yang mempunyai kepentingan politik dimana disinyalir pemerintah banyak orang Tionghoa terlibat didalamnya. Hal ini menjadi dasar pemerintah pada saat itu mengeluarkan Instruksi Presiden No. 14 Tahun 1967 Tentang Agama Kepercayaan dan Adat Istiadat Cina, yang berisi pelarangan pelaksanaan peribadatan cina secara umum dan terbuka dan diharuskan dilakukan secara pribadi dan tertutup dengan alasan menghambat proses asimilasi atau pembauran rakyat Indonesia yang plural secara keseluruhan. Hal ini berdampak sangat besar bagi umat 
khong hucu pada saat itu karena dengan berlakunya instruksi presiden tersebut maka segala aktifitas keagamaan secara keseluruhan di larang dan ini menjadi awal diskriminasi pada agama serta umatnya tersebut.

4. Tahun 1969 muncullah Undang-undang No. 5 Tahun 1969 pengganti Keputusan Presiden Nomor 1 Tahun 1965 Tentang 6 Agama Resmi di Indonesia, dan agama khonghucu termasuk salah satu agama resmi didalamnya namun karena ada Instruksi Persiden No. 14 Tahun 1967 yang baru berlaku pada saat itu maka keberadaan agama khonghucu menjadi beku.

5. Tahun 1974 lahir kebijakan baru yang berkaitan dengan hukum perkawinan yaitu Undang-undang No. 1 Tahun 1974 Tentang Perkawinan. Yang mana dinyatakan bahwa bagi seluruh rakyat Indonesia dari semua golongan dan suku dalam hal perkawinan wajib melaksanakan perkawinannya itu dengan berpedoman pada Undang-undang tersebut. Hal ini mengartikan bahwa Hukum Adat, Hukum Islam, Hukum Perdata Barat, Hukum Perkawinan Kristen Indonesia, dan Hukum Perkawinan Campur (Reglement Gemengde Huwelijken/ RGH) tidak berlaku lagi. Dan diperkuat dengan terbitnya Peraturan Pemerintah (PP) No. 9 Tahun 1975 Tentang Pelaksanaan Undang-undang No. 1 Tahun 1974. Berikut kutipan Pasal 2 ayat (1) Undang-undang No.1 Tahun 1974 Tentang Perkawinan,

"Perkawinan adalah sah, apabila dilakukan menurut hukum masing-masing agamanya dan kepercayaannya itu”.

6. Tahun 1978, Menteri Dalam Negeri mengeluarkan keputusan dalam bentuk Surat Edaran No. 477 Tahun 1978 yang menyatakan bahwa hanya ada 5 (lima) agama resmi 
yang diakui oleh Pemerintah Indonesia yaitu Islam, Kristen, Katholik, Hindu, dan Budha. Dimana dengan surat edaran tersebut Agama Khonghucu tidak masuk didalamnya, hal ini membawa dampak perkawinan secara Agama Konghucu tidak bisa dicatatkan di kantor catatan sipil.

Demikian kajian sementara, alasan kenapa dalam waktu lama Agama Khonghucu beku di Indonesia.

Dalam masa pembekuan Agama Khong hu cu banyak hal yang terjadi pada umatnya yang dirasa tidak enak dan nyaman baik sebagai umat maupun sebagai warga negara karena status hukum yang tidak jelas yang mengakibatkan diskriminasi yang luar biasa baik secara formal maupun spiritual. Karena saat sejak itu banyak sekolah khong hu cu di tutup, tempat ibadah di tutup, identitas mereka rancu, status anak dari hasil perkawinan para umat tidak jelas karena tidak bisa dicatatkan secara hukum, dan mendapat sanksi sosial dari lingkungan tempat tinggal mereka. Akhirnya karena keadaan yang demikian, banyak umat Khonghucu yang menyamarkan identitas mereka yang sesungguhnya dan yang lebih menyedihkan bagi mereka adalah tidak adanya batas waktu masa pembekuan itu. Sebagai contoh nyata yang penulis dapatkan dari penelitian yang dilakukan pada tanggal 22 januari 2015 adalah hasil wawancara dari sepasang suami istri yang beragama khong hucu bernama Gunadi dan Indra Yanah di Desa Curug Gunung Sindur. Mereka menikah pada tanggal 15 September 1996 dan pernikahannya tidak bisa dicatatkan di kantor catatan sipil yang otomatis tidak mendapatkan akta perkawinan, mereka hanya menikah secara agama saja, Namun walaupun mereka menikah hanya secara agama saja mereka tetap mendapatkan surat nikah yang bernama LIEP- 
Siti Nurwullan

GWAN dari tempat ibadah dimana mereka menikah, berikut kutipan sekaligus lampiran LIEP-GWAN:

KUTIPAN

SURAT LIEP-GWAN PERNIKAHAN

TERDAFTAR DAN DILAKSANAKAN

DI:

KAKIN - CURUG GUNUNG SINDUR

No. 069/ pm./Lth./LC/1996

Menerima Liep-Gwan Pernikahan pada hari Minggu,

Tanggal : 15 September 1996 jam: 14.00

Di pimpin oleh : “BS. TAN TJOE SENG “

Saudara GUNADI

Lahir di Bogor pada tanggal 26 Juli 1970

Putra Tn. GOUW SUN OK dan Ny. THE E NOK

Dengan

Saudari INDRA YANAH

Lahir di Bogor pada tanggal 04 Februari 1972 
Putri Tn. TJIAW MINGGU (INGGU GAMPANG)

Ny. ERAH WATI

Disaksikan oleh : Sdr. TONNY.H dan Sdr. KADE

Siancai !

CURUG, 15 SEPTEMBER 1996

a.n. MATAKIN

(OCIN OSANTO)

Pimpinan Makin/Kebaktian/Klenteng/Bio

Dari kutipan LIEP-GWAN di atas dinyatakan bahwa telah dilangsungkan pernikahan antara Saudara Gunadi dan Saudari Indra Yanah pada tanggal 15 September 1996 dan telah tercantum bahwa pernikahan tersebut dilangsungkan secara agama. Pertanyaan di benak penulis adalah bagaimana dengan anak-anak keturunan mereka untuk akta kelahiran dan KTP karena akan menimbulkan akibat hukum bagi keluarga mereka?, dikarenakan keadaan yang sedemikian rupa banyak masyarakat dari etnis Tionghoa yang kemudian mengganti agama dan nama mereka di KTP (Kartu Tanda Penduduk) menjadi salah satu agama dari lima (5) agama resmi di Indonesia tersebut sesuai Keputusan Surat Edaran No. 477 Tahun 1978. Banyak dari mereka mengganti 
agama Konghucu dengan agama Kristen, Katolik dan Budha, setelah mereka mengganti agamanya baru mereka dapat mencatatkan perkawinan mereka di kantor catatan sipil dan mendapatkan akta nikah sebagai bukti bahwa perkawinan mereka sah secara hukum dan telah sesuai dengan pedoman Undangundang No 1 Tahun 1974 Tentang Perkawinan.

Tetapi tidak sedikit pula dari masyarakat Tionghoa yang bertahan dengan keyakinan dan agamanya Khonghucu, mereka memilih tidak dicatatkan secara hukum dan anak-anak dari hasil perkawinan mereka hanya mendapatkan akta kelahiran yang statusnya anak dari ibunya saja. Itulah keadaan para penganut Agama Khong hu cu selama dalam pembekuan tidak hanya berpengaruh pada perkawinan mereka tetapi juga pada pelaksanaan administrasi lainnya seperti KTP, Akta Kelahiran, bahkan pendidikan agama yang hanya dibolehkan pada lima agama resmi saja.

Seiring waktu berjalan, dunia politik Indonesia mengalami pasang surut, di tahun 1998 masa Orde Baru jatuh dengan lengsernya Presiden Soeharto sebagai presiden Republik Indonesia di gantikan oleh wakilnya yaitu Wakil Presiden BJ Habibie pada saat itu. Masuk era Reformasi di tahun 1999, pemilihan umum Presiden berlangsung dan dimenangkan oleh Presiden Abdul Rahman Wahid dengan Wakil Presiden Megawati.

Di tahun 2000 tepatnya di tanggal 17 Januari 2000, Presiden Abdul Rahman Wahid mencabut Inpres No. 14 Tahun 1967 Tentang Agama, Kepercayaan dan Adat Istiadat Cina dengan diterbitkannya Keppres No. 6 Tahun 2000 Tentang Pencabutan Instruksi Presiden Nomor 14 Tahun 1967 Tentang Agama, Kepercayaan dan Adat Istiadat Cina. Sejak saat itu para penganut Agama Khonghucu sudah bisa kembali melaksanakan ritual 
keagamaannya secara bebas dan terbuka. Namun tidak secara administrasi karena selama belum ada ketentuan yang mendukung kepres tersebut pelaksanaan secara administrasi untuk para penganut agama konghucu belum bisa dilakukan.

Tahun 2006 terbitlah Surat Edaran Menteri Agama No. 12/MA/2006 Tentang status perkawinan menurut Agama Konghucu dan pendidikan Agama Konghucu, yang diikuti dengan diterbitkannya Surat Edaran Menteri Dalam Negeri No. 470/336/SJ pada tanggal 24 Januari 2006 Tentang Pelayanan Administrasi Kependudukan Penganut Konghucu. Sejak itu kebebasan, kepastian hukum, status hukum para penganut Agama Konghucu baik sebagai orang beragama dan warga negara kembali diperoleh. Namun dampak dari pembekuan yang lama tidak bisa serta merta memperbaiki keadaan administrasi mereka. Semua berjalan bertahap hingga pulih.

Dalam penelitian berikutnya yang dilakukan Penulis di tanggal 21 Januari 2019, didapatkan data salah seorang penganut Agama Khonghucu yang menikah di tahun 2017, dengan data sebagai berikut :

Nama suami

: CUI LAY

Nama istri : HERIYANTI

Tempat tanggal lahir suami : Tangerang, 28 Mai 1984

Agama yang di anut

: Khong hu cu

Alamat rumah : Jalan Raya Pemuda, Desa Pendurenan, RT 04/03, Gunung Sindur Bogor.

Tempat ibadah : Lithang, Bio, Klenteng

Tanggal pernikahan

: 22 Januari 2017

Tempat menikah : MAKIN CURUG GUNUNG SINDUR

Tanggal didaftarkan ke kantor catatan sipil : 13 Januari 2018 
Siti Nurwullan

Kantor tempat pencatatan

: DUKCAPIL Cibinong

Bogor

Bukti legalitas yang didapatkan dari

kantor catatan sipil

: Akta Perkawinan.

Dari hasil data di atas menunjukkan bahwa secara administrasi yaitu status hukum dan kepastian hukum sebagai warga negara penganut agama konghucu sudah pulih kembali.

Kutipan Kitab Su Si, Lun Gi : Jilid XII :19

"Kebajikan seorang pembesar laksana angin, dan kebajikan rakyat laksana rumput, kemana angin bertiup, kesitu rumput mengarah!". Demikian paparan hasil penelitian penulis untuk judul tersebut di atas.

\section{KESIMPULAN}

1. Berdasarkan hasil penelitian, legalitas perkawinan secara Agama Khong hucu di tinjau dari Undang-undang No. 1 Tahun 1974 Tentang perkawinan adalah sah karena selain karena ketentuan dari Undang-undang tersebut sudah sejalan atau sinkron, juga karena Khonghucu adalah salah satu agama yang mempunyai pemuka dan kitab suci sebagai acuan dan pedoman dalam ajarannya serta sudah kembali menjadi salah satu agama resmi di Indonesia.

2. Akibat hukum yang negatif bagi para penganut Agama Khonghucu saat ini bertahap sudah berkurang dan mulai kembali pulih, terbukti dengan hasil penelitian yang dilakukan penulis pada tanggal 21 Januari 2017.

\section{SARAN}


1. Dengan kembalinya Agama Khonghucu menjadi salah satu agama resmi Indonesia diharapkan pembekuan yang pernah terjadi bisa lebih merekatkan dan mengeratkan rasa persaudaraan antar suku dan agama.

2. Agar pihak terkait untuk lebih giat mensosialisasikan kebijakan ini agar pemulihan secara menyeluruh bisa cepat terealisasi.

\section{DAFTAR PUSTAKAN}

\section{A. BUKU}

Soetandyo Wignyosoebroto, Perspektif Pekawinan Ditinjau Dari Sudut Hukum, Sosial dan Agama Khonghucu. Surabaya : Penelitian dan Pengembangan Majelis Agama Khonghucu Indonesia. Edisi II Boen Bio, 1997

Burhan Ashshafa, "Metode Penelitian Hukum", Rineka Cipta,Jakarta ,2002

Djaja S Meliala, Himpunan Peraturan Perundang-Undangan Tentang Perkawinan, angka 2 penjelasan UU No 1 Tahun 1974, Nuansa Aulia, Bandung, 2008.

Hazairin. Hukum Kekeluargaan Nasional

Indonesia. Jakarta: Tintamas, 1961.

Hilman Hadi Kusuma,"Hukum Perkawinan Indonesia", Mandar Maju,Bandung, 1990.

Hosen Ibrahim. Figih Perbandingan Dalam Masalah Nikah, Talak dan Rujuk. Jakarta: Ilya Uluudin, 1971.

K.Watjik Saleh. Hukum Perkawinan Indonesia. Jakarta: Ghalia Indonesia, 1976.

Mengzi VII A: 38

Marcus A S,Hari-hari Raya Bangsa Tionghoa, Marwin Jakarta, 2003.

Matakin."Kitab Suci Yak King ～I Ching )’, Matakin,Solo,2535. 
4),2012.

----------., Tata Aturan Dewan Rohaniawan Agama Khonghucu Indonesia

Beserta Berbagai Panduan Tata Upacara dan Kode Etik Rohaniawan, Edisi khusus, 2010.

---------, Kitab Si Shu ,Zhong Yong BAB XIX, pasal 8,2012.

Nasution, Khoirudin, Status Wanita Di Asia Tenggara studi terhadap Perundang-undangan Muslim Kontemporer di Indonesia dan Malaysia,INIS,Jakarta,2002

Nio Joe Lan, Peradaban Tionghoa Selayang Pandang,

Gramedia, Jakarta,2005

Sudarsono. Hukum Perkawinan Indonesia. Jakarta: Rineke Cipta, 1991.

Soetandyo Wignyosoebroto,Perspektif Perkawinan Ditinjau Dari Sudut Hukum,Sosial, dan Agama Khonghucu. Surabaya : Penelitian dan Pengembangan Majelis agama Khonghucu Indonesia, Edisi II Boen Bio,1997.

\section{B. UNDANG-UNDANG}

Undang- undang Dasar 1945

Undang-undang No. 1 Tahun 1974 Tentang Perkawinan

Penetapan Presiden Republik Indonesia No. 1 Tahun 1965

tentang Pencegahan Penyalahgunaan dan atau Penodaan Agama

Undang-undang No. 5 Tahun 1969 pengganti Keputusan Presiden Nomor 1 Tahun 1965 Tentang 6 Agama Resmi di Indonesia

Instruksi Presiden No. 14 Tahun 1967 Tentang Agama Kepercayaan dan Adat Istiadat Cina 
Keputusan Presiden Republik Indonesia No. 6 Tahun 2000 Tentang Pencabutan Instruksi Presiden No. 14 Tahun 1967 Tentang Agama, Kepercayaan, dan Adat Istiadat Cina Peraturan Pemerintah (PP) No. 9 Tahun 1975 Tentang Pelaksanaan Undang-undang No. 1 Tahun 1974 Surat Edaran No. 477 Tahun 1978 yang menyatakan bahwa hanya ada 5 (lima) agama resmi yang diakui oleh Pemerintah Indonesia

Surat Edaran Menteri Agama No. 12/MA/2006 Tentang status perkawinan menurut Agama Konghucu dan pendidikan Agama Konghucu

Surat Edaran Menteri Dalam Negeri No. 470/336/SJ Tentang Pelayanan Administrasi Kependudukan Penganut Konghucu

\section{ARTIKEL DAN WEBSITE}

http://www.uinjkt.ac.id/diera-orde baru-budaya-cina-berbaukomunis

www.spocjournal.com/hukum/300.legalitas agama khonghucu di indonesia 